\title{
Effect of Pyramid and Reversed Pyramid Load Exercise on Arm and Thigh Muscle Hypertrophy
}

\author{
Indra*, YanuarKiram \\ Faculty of Sport Science \\ Universitas Negeri Padang \\ Padang, Indonesia
}

\begin{abstract}
This study aims to determine the effect of pyramid weight training methods and an inverted pyramid on the arm and thigh muscle hypertrophy of fitness club members. This type of research is a quasi-experimental that involved 24 samples. Measurement of arm and thigh muscle hypertrophy used meter tape and skinfold. To calculate the arm and thigh muscle circumference, the formula MTC(3.14 $x$ TSF) is used. Data were analyzed by t-test at a significance level of $\alpha=0.05$. The results showed that (1) there was an effect of the pyramid weight training method on arm muscle hypertrophy, with $t_{\text {count }}=18.57>t_{\text {table }}=1.80$, (2) there was the influence of the pyramid weight training method on thigh muscle hypertrophy, with $t_{\text {count }}=23,35>t_{\text {table }}$ $=1.80$, (3) there is an effect of the inverse pyramid load training on arm muscle hypertrophy, with $t_{\text {count }}=\mathbf{7 . 8 4}>t_{\text {table }}$ $=1.80,(4)$ there is the influence of the pyramid load training method on muscle hypertrophy thigh, with $t_{\text {count }}=7.90>t_{\text {table }}$ $=1.80$, (5) pyramid weight training method gives a better influence than the inverse pyramid load training method for arm muscle hypertrophy, with $t_{\text {count }}=3.33>t_{\text {table }}=1.72$, and (6) pyramid weight training method gives a better effect than the inverse pyramid load training method to thigh muscle hypertrophy, with $t_{\text {count }}=2.05>t_{\text {table }}=1.72$. In other words, the pyramid weight training method provides a better effect than the inverse pyramid weight training method for arm and thigh muscle hypertrophy.
\end{abstract}

Keywords-pyramid, reverse pyramid, arm, thigh muscle hypertrophy

\section{INTRODUCTION}

Weight training is seen as a popular and widely practiced sport today with many people joining fitness centers. Weight training can be done using a load of his own weight and using external weights. Forms of exercises that use external loads can be free weight such as using Dumbell, Barbell, or a load machine (Gym Machine). While the form of exercises that use deep loads such as Chin-Up, Push-Ups, Sit-Ups, Back-Ups and so on. "Weight training is a form of exercise that uses media load tools to support the training process with the aim of improving fitness, muscle strength, speed, muscle tightening, muscle hypertrophy, rehabilitation, and weight gain and reduction"[1].

Weight training that is carried out regularly and programmed and in accordance with the basic principles of exercise will result in better muscle development and formation or increase in muscle mass to be greater (hypertrophy). "Weight training will cause enlargement of the muscles caused by: (1) enlarged muscle fibers (muscle hypertrophy), (2) increased number of capillaries in the muscle, (3) increase connective tissue in the muscle "[2]. "Muscle hypertrophy is an increase in the size of muscle cells. This is different from muscle hyperplasia, which is the formation of new muscle cells "[3]. "the occurrence of muscle hypertrophy is a result of increasing the number of Myofibrils in each muscle fiber, increasing the density (density) of capillaries in each muscle fiber, increasing the amount of protein, and increasing the number of muscle fibers"[4].

When the mass of a muscle becomes large due to an increase in the amount of Actin and Myosin in each muscle fiber, this event occurs as a response to muscle contractions that take place at maximum strength. Very wide hypertrophy can occur if during the contraction process the muscles are stretched simultaneously for a maximum of 6-10 weeks. If the contraction is very strong, the amount of Actin and Myosin Filament increases progressively in Myofibril, Myofibrils will break in each muscle to form new Myofibril [5].

In weight training, there are large muscles that need to be trained to get an ideal and proportional body such as the muscles in the arms, chest, abdomen, and muscles in the thighs. These muscles have a very important role in the human body, ranging from rejecting, hitting, lifting, walking and so on. One of the big muscles that plays a role in the body is the muscles in the arms and thighs. There are many weight training methods that can be used to improve the hip and hypertrophy of the thigh muscles such as Super Set Training, Compound Set, Triset, Giant Set, Pyramid, Drop Set, Circuit Training, slow motion training, and fast motion weight training.

One method of weight training that can be used to improve arm and thigh muscle hypertrophy is the Pyramid method. Pyramid weight training method is a method of training carried out by carrying out force loads starting from a lower intensity with multiple replications then gradually heading to a higher intensity with a slight replication. the Pyramid system, better known as Pyramid Training, is a special method used to increase or develop strength[6]. This Pyramid system exercise is characterized by a constant increase in outer load (load intensity) 
accompanied by a decrease in the number of repetitions (repetitions) per set. In other words, an increase in load intensity (load weight) is carried out together with a decrease in the number of repetitions or repetitions.

While the method of inverted Pyramid load training is the opposite of the Pyramid weight training method, which is a slight initial repetition and maximum given load, and the next set of repetitions increases, then the training load decreases. "Inverted Pyramid training is a form of exercise that begins with heavy loads, little repetitions, and ends with light loads and many repetitions "[7].

Metro Gym is one of the many fitness centers in the city of Padang that provide a variety of training tools, so that a variety of exercises and types of exercises can be done, plus a Personal Trainer who guides in undergoing training so that Members can easily form proportional muscles. Based on the observation of the author and information from the owner of Fitness, that most of the members are only able to survive 3-4 months, because after several months of exercise they do not get the results they want to achieve, namely enlargement of muscle mass (Hypertrophy). Some members still cannot choose an appropriate training method to produce and improve muscle hypertrophy and determine a regular exercise program. This is due to the fact that many members are less aware of training programs and weight training methods. Although it has been guided by a Personal Trainer, but some Members prefer to undergo excessive training or not in accordance with the principles of exercise, so that the main goal of muscle hypertrophy is not achieved. In addition, most of the members also do not pay attention to resting patterns, coupled with a lack of Member knowledge about muscle-building nutrients.

Based on the problems mentioned above, the authors feel interested in doing a study in order to form an ideal and proportional body or increase muscle mass, which is about the influence of Pyramid weight training methods and reverse pyramid on arm and thigh muscle hypertrophy in Fitness Member Gym Metro Gym Purus City of Padang, so the results of this study can be corrective in the future in producing hypertrophy of the muscles of the arms and thigh muscles.

\section{RESEARCH METHODS}

The method used in this study is quasi-experimental (Quasy Experiment Design). While the experimental design used in this study is Two-Group Pretest-Posttest Design. "in this design there are pretest before being given treatment, the treatment results can be known accurately, because it can compare with the situation before given treatment "[8].

In this study, there were two treatment groups namely, 1) groups treated with Pyramid weight training methods and, 2) groups treated with the reverse Pyramid weight training method. The treatment was given 16 times, then measured (Posttest).
This research was conducted at Metro Gym Bandar Purus Fitness Center, Padang City. The population in this study were Member Fitness Metro Gym Bandar Purus, Padang City, which was registered from December 2018 to March 2019 and actively participated in 154 exercises. Sampling in this study used purposive sampling technique. "Purposive Sampling is a technique of determining samples based on consideration of the objectives set by the researcher"[9]. Based on the Sampling technique, the number of samples in this study were 24 members of the Fitness Metro Purus Bandar Gym City of Padang.

Measurement of arm and thigh muscle hypertrophy using meter tape and skinfold. The tape measure aims to measure muscle circumference and skinfold aims to measure the thickness of fat in the muscle. Next, the formula is used as follows: MMC $=$ MMC- $(3.14 \times \mathrm{TSF})$.

Treatment was given with an intensity of $70 \%-85 \%$ according to the muscle hypertrophy program. The form of weight training carried out in accordance with this study is for the muscles of the arms and thigh muscles.

After all the data has been collected, it is then compiled and analyzed statistically through the analysis requirements testing process. The prerequisite test for the analysis is the normality test and the variance homogeneity test. Then, hypothesis testing is done by using the t-test.

\section{RESULTS AND DISCUSSION}

Based on the results of the one hypothesis test, data obtained from muscle hypertrophy of the tcount $=18.57>$ $\mathrm{t}$ table $=1.80$, the value of the Pretest average $=269.73$ and Posttest $=291.03$, with the average difference $=$ 21.29. In other words, it can be concluded that Ho is rejected and $\mathrm{Ha}$ is accepted. That is, there is the influence of the Pyramid load training method on arm muscle hypertrophy in the Member Fitness Metro Gym Bandar Purus, Padang City.

Based on the results of the two hypothesis test, data obtained from thigh muscle hypertrophy count $=23.35>\mathrm{t}$ table $=1.80$, the value of the Pretest average $=461.26$ and Posttest $=488.78$, with the average difference $=27.52$. In other words, it can be concluded that Ho is rejected and $\mathrm{Ha}$ is accepted. That is, there is the influence of the Pyramid load training method on thigh muscle hypertrophy in the Member Fitness Metro Gym Bandar Purus, Padang City.

Based on the results of the three hypothesis test, data obtained from arm muscle hypertrophy tcount $=7.84>\mathrm{t}$ table $=1.80$, the value of the Pretest average $=263.20$ and Posttest $=272.36$, with the average difference $=9.17$. In other words, it can be concluded that Ho is rejected and $\mathrm{Ha}$ is accepted. That is, there is an effect of the inverse Pyramid load training method on arm muscle hypertrophy in the Member Fitness Metro Gym Bandar Purus, Padang City.

Based on the results of the four hypothesis test, data obtained on thigh muscle hypertrophy count $=7.90>\mathrm{t}$ 
table $=1.80$, the value of the pretest average $=462.93$ and Posttest $=470.19$, with an average difference $=7.26$. In other words, it can be concluded that Ho is rejected and $\mathrm{Ha}$ is accepted. That is, there is an influence of the inverse Pyramid load training method on thigh muscle hypertrophy in the Member Fitness Metro Gym Bandar Purus, Padang City.

Based on the results of the five hypothesis test, obtained data of muscle hypertrophy of arm tcount = $3.33>\mathrm{t}$ table $=1.72$, mean value of Posttest Arm muscle hypertrophy in the treatment group Pyramid weight training method $=291.03$ and the mean value of Posttest Muscle Hypertrophy arm of the treatment group inverted Pyramid load training method $=272.36$. Furthermore, the average difference in arm muscle hypertrophy in the treatment group Pyramid weight training method $=21.29$ and arm muscle hypertrophy group treatment method reverse Pyramid load training $=9.17$. In other words, it can be concluded that $\mathrm{Ho}$ is rejected and $\mathrm{Ha}$ is accepted. That is, there are differences in the effect of the Pyramid load training method and the inverse Pyramid load training method on arm muscle hypertrophy in the Member Fitness Metro Gym Bandar Purus, Padang, where the Pyramid weight training method gives a better effect than the inverse Pyramid weight training method for arm muscle hypertrophy. at Member Fitness Metro Gym Bandar Purus, Padang City.

Based on the results of the six hypothesis test, obtained data on thigh muscle hypertrophy count $=2.05>\mathrm{t}$ table $=$ 1.72, the average value of Posttest Thigh muscle hypertrophy in the treatment group Pyramid weight training method $=488.78$ and the average value of Posttest Muscle Hypertrophy thigh treatment group method of reverse Pyramid load training $=470,19$. Furthermore, the average difference in thigh muscle hypertrophy treatment group Pyramid weight training method $=27.52$ and thigh muscle hypertrophy treatment group reverse Pyramid load training method $=7.26$. In other words, it can be concluded that Ho is rejected and $\mathrm{Ha}$ is accepted. That is, there are differences in the influence of the Pyramid load training method and the inverse Pyramid load training method on thigh muscle hypertrophy in the Member Fitness Metro Gym Bandar Purus, Padang, where the Pyramid weight training method gives a better effect than the inverse Pyramid weight training method for thigh muscle hypertrophy at Member Fitness Metro Gym Bandar Purus, Padang City.

Weight training that is done regularly and programmed and in accordance with the basic principles of exercise will result in better muscle development and formation or increase in muscle mass to be greater (hypertrophy). Pyramid weight training method is one of the many weight training methods that can be used to increase muscle hypertrophy. Another form of Pyramid load training method is the upside down pyramid.

Pyramid weight training method is a method of training carried out by carrying out force loads starting from a lower intensity with multiple replications then gradually heading to a higher intensity with a slight replication. While the method of Pyramid inverted weight training is a method that is almost the same as the Pyramid training method, but the initial repetition is small and the load is given maximum, and the next set of repetitions increases, but the training load decreases.

Pyramid load training methods are characterized by a constant increase in outer load (load intensity) accompanied by a decrease in the number of repetitions (repetitions) per set. In other words, an increase in load intensity (load weight) is carried out together with a decrease in the number of repetitions or repetitions. the Pyramid training method had a better influence on the increase in muscle hypertrophy in the arm and thigh muscles compared to the inverted Pyramid training method. Whereas the reverse Pyramid system can increase Aerobic Power, Anaerobic Power, and Agility but cannot increase Flexibility [7].

Based on the description, it can be concluded that Member Fitness Metro Gym Bandar Purus, Padang City, which is given the Pyramid and Pyramid inverted weight training methods and in accordance with the principles of exercise, will result in arm and thigh muscle hypertrophy. But in terms of effectiveness, the Pyramid weight training method gives a better effect than the inverse Pyramid weight training method for arm and thigh muscle hypertrophy. This is due to the characteristics of each weight training method, where the Pyramid method is characterized by a constant increase in external load (load intensity) accompanied by a decrease in the number of repetitions / sets or performed by carrying a load force starting with more intensity low with a lot of repetition then gradually towards a higher intensity with a little repeat. In other words, the Pyramid weight training method gives a good effect on muscles without experiencing significant fatigue in the muscles, so the muscles do not need a long time for recovery. While the upside down pyramid is a training method with a small initial repetition and the maximum load is given, and the next set of repetitions increases, but the training load decreases. In other words, the muscles are forced to contract because it starts with a high intensity so that the muscles will quickly experience fatigue and require a long time for recovery.

\section{CONCLUSIONS}

1. There is the influence of the Pyramid weight training method on arm muscle Hypertrophy in Member Fitness Metro Gym Bandar Purus, Padang City, with tcount $=18.57>\mathrm{t}$ table $=1.80$.

2. There is the influence of the Pyramid weight training method on thigh muscle hypertrophy in Member Fitness Metro Gym Bandar Purus, Padang City, with thitung $=23.35>$ t table $=1.80$.

3. There is the effect of the inverse Pyramid load training method on arm muscle hypertrophy in Member Fitness Metro Gym Bandar Purus, Padang City, with thitung = $7.84>\mathrm{t}$ table $=1.80$. 
4. There is the influence of the inverse Pyramid load training method on thigh muscle hypertrophy in Member Fitness Metro Gym Bandar Purus, Padang, with thitung $=7.90>\mathrm{t}$ table $=1.80$.

5. Pyramid weight training methods provide a better influence than the inverse Pyramid load training method for arm muscle hypertrophy in Member Fitness Metro Gym Bandar Purus City of Padang, with thitung $=3.33>\mathrm{t}$ table $=1.72$.

6. The Pyramid weight training method gives a better effect than the inverse Pyramid load training method for thigh muscle hypertrophy in Member Fitness Metro Gym Bandar Purus, Padang City, with thitung = 2.05> t table $=1.72$.

\section{REFERENCES}

[1] D.P. Irianto. "Materi Pelatihan Instruktur Fitness Tingkat Dasar". Yogyakarta: Klinik Kebugaran FIK UNY. 2004, pp. 70.

[2] H.Y.S.S. Giriwijoyo. "Ilmu Faal Olahraga (Fisiologi Olahraga) Fungsi tubuh Manusia pada Olaharaga Untuk Kesehatan dan Prestasi”. Bandung: PT Remaja Rosdakarya Offset. 2013, pp. 25.

[3] Bafirman. "Fisiologi Olahraga". Malang: Wineka Media. 2013, pp. 35.

[4] Sukadiyanto. "Pengantar Teori dan Metodologi Melatih Fisik". Yogyakarta: FIK UNY. 2011, pp. 45.

[5] Syaifuddin. "Anatomi Fisiologi Untuk Mahasiswa Keperawatan Edisi 3". Jakarta: Penerbit Buku Kedokteran EGC. 2011, pp. 47.

[6] Syafruddin. "Perangkat Pembelajaran Ilmu Melatih Dasar". Padang: FIK UNP. 2017, pp. 56.

[7] S . Arhesa. "Efektifitas Metode Latihan Piramid dan Piramid Terbalik terhadap Peningkatan Hipertrofi Otot Dada dan Kekuatan Otot Dada pada Atlet Binaraga Jawa Barat", Prosiding Seminar Nasional Pendidikan Jasmani Olahraga, pp. 45-51. 1 Oktober 2016.

[8] Sugiyono. " Metode Penelitian Kuantitatif, Kualitatif dan R \& D”. Bandung: CV AlFABETA. 2011, pp. 23.

[9] E. Barlian. "Metodologi Penelitian Kualitatif \&Kuantitaif”. Padang: Sukabina Press. 2016, pp. 42. 